\title{
A Study on the Impact of Consumer Ethics on Apparel Purchasing Behavior
}

\author{
Hongshan ZHAO* \\ Beijing Institute of Fashion Technology, Beijing, China
}

\begin{abstract}
As the Chinese economy grows fast and the Chinese residents' spending power increases, "ethical consumers" have been lavished with increasing attention. In fact, consumption has become a decision-making process closely tied to ethics or morality. This article describes consumers' basic cognition of environmental issues and ethical apparel in a quantitative manner. The research covers mainly the following topics: consumers' understanding and recognition of ethical apparels, factors bearing on the behavior of purchasing ethical apparels, surveys of the intentions of consumers to purchase ethical apparels as well as the personal information of survey respondents. The purpose is to provide forward-looking bases and reference for apparel enterprises to plan ethical marketing.
\end{abstract}

Keywords: Consumption, Consumer Ethics, Consumer Ethical Behavior, Apparel Ethical Marketing.

\section{Introduction}

A study of the UK consumers and producers indicates that a growing number of people begin to realize that the production and consumption of apparel may deal a negative impact on ecological environment. As a result, the textile and apparel industries have seen increasingly prevalent ethical consumption. In the business history of the US, there were exemplary enterprises that have both seen success and observed ethics. Warren Buffett mentioned in a speech for students of the University of Columbia Business School that "In this country, those complying with ethical norms can harvest great success. Ethics will not burden you. Sometimes, it is neutral; sometimes, it can even lend you a helping hand. But it is by no means a burden to you." From a long-term perspective, the core of business is none other than relations and trust, so an ethical way of doing business is no doubt the ultimate way to success.

As a special consumer segment, "ethical consumers" have drawn increasing attention. Because consumers of this type have a deep sense of responsibility with respect to environment and society and attempt to articulate their appeals on ethical values through ethical purchasing or resistant behavior, consumption for them has almost become a decisionmaking process closely tied to ethics or morality. The attention to and belief in ethical issues can effectively shape consumers' purchasing behavior. This article aims to investigate and

\footnotetext{
* Corresponding author: sxyzhs@bift.edu.cn
} 
analyze the impact of consumer ethics on apparel purchasing decisions. Its conclusions may provide some reference for enterprises to undertake ethical fashion marketing.

\section{Connotation of the view of consumer ethics}

The view of consumer ethics is a compound notion. It has always been the most crucial dominant part of consumer attitude. It is a result of mutual assimilation between the notion of consumer ethics and the notion of consumer attitude. The view of consumer ethics refers to ideological concepts that have taken shape by making certain moral evaluation of various consumption styles and behaviors that occur in everyday life and that are used to guide specific consumption behaviors.

The view of consumer ethics is based on the consumer ethics, and is in itself a subjective consciousness within the notion of consumer ethics. The importance of consumer ethics view finds expression in the fact that it directly bears on the consumption style and behavior of an individual or a particular consumer group. In fact, the consumer ethics view always uses ethical or moral standards to understand or evaluate consumer behaviors. To put it simple, if a consumption concept is of ethical nature, it is then a view of consumer ethics, for it constantly focuses on whether a consumption behavior is justifiable or not and whether it enables people to live a happy life or not.

\section{Theoretical foundation}

In the consumer behavior research area, an absolute majority of scholars believe that intention is the most important indicator of behavior. Therefore, to correctly understand the ethical consumption behavior of a consumer with regard to apparel, we must first of all examine his/her ethical purchasing intention. Intention means the degree to which a consumer attempts to perform a particular behavior [1] or the level of effort he/she is willing to make in order to achieve a particular behavior [2]. For researching purchasing intention, the theory of planned behavior is considered to be one of the most powerful models. Many empirical studies have demonstrated the capability of the planned behavior theory to explain various behavioral intentions. In reality, however, ethical purchasing decisions of a consumer are quite complicated. As Boulstridge and Carrigan [3] see it, consumers may care about the ethical behavior of an enterprise, but do not necessarily have the intention to do ethical purchasing, nor do they necessarily support ethical products or resist non-ethical products. This article examines the factors that affect consumers' ethical purchasing behaviors based on the planned behavior theory. 


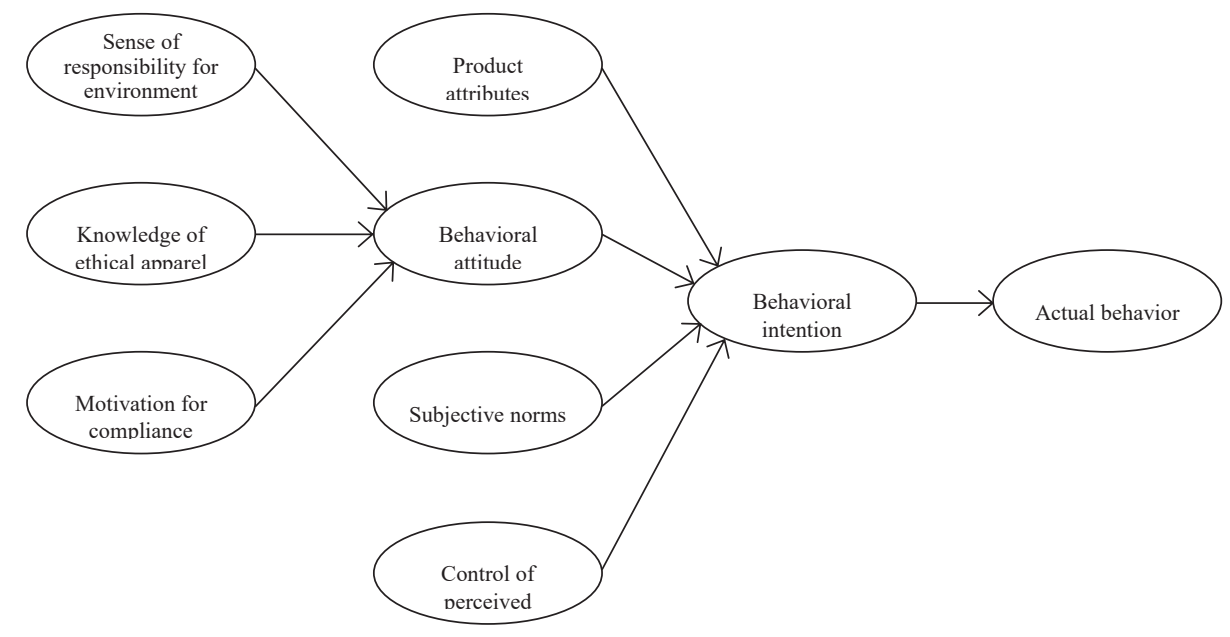

Fig. 1. Research Model Adopted by This Article.

Based on previous studies, this article explores from the psychological perspective the relationship between product attributes, behavioral attitude, subjective norms and control of perceived behavior on one side and the intention to purchase ethical apparel on the other side. In particular, this article holds that we should examine the behavioral attitude of a consumer in terms of the sense of responsibility for environment, the knowledge of apparel ethics, and the motivation for compliance. The research model is charted in Figure 1. On this basis, this article puts forward the following hypotheses:

H1: Product attributes have significant positive effect on the ethnical purchasing intention of a consumer.

$\mathrm{H} 2$ : Behavioral attitude has significant positive effect on the ethnical purchasing intention of a consumer.

H3: Subjective norms have significant positive effect on the ethnical purchasing intention of a consumer.

H4: Control of perceived behavior has significant positive effect on the ethnical purchasing intention of a consumer.

This article selects some factors that have relatively greater influence on the purchasing of ethical apparel. Such factors primarily include the following:

\subsection{Product attributes}

The attributes of apparel products include prices, colors, styles, fabric and workmanship, among others. Moreover, the attributes of apparel products are consistent with purchasing intention, so much so that the good quality and reasonable price of an apparel product would positively bolster the purchasing intention of a consumer.

\subsection{Behavioral attitude}

Behavioral attitude represents a person's willingness to perform a particular behavior in a given context, as well as his/her assessment, whether positive or negative [4], of the behavior in its entirety. Based on previous studies, this article examines the impact of three factors, namely, the sense of responsibility for environment, the knowledge of apparel ethics and the 
motivation for compliance, on the behavioral attitude of consumers. The first two factors are relatively easy to understand, and the third, i.e. the motivation for compliance, is the willingness of an individual to perform ethical consumption behavior by complying with the intention of other persons important to him/her. Chinese consumers tend to comply with social norms or the expectations of others, the collective or a group. Those who motivate consumers to comply with include not only family members, friends and colleagues, but also government, media and consumer protection groups.

\subsection{Subjective norms}

Subjective norms mainly refer to the impact of external social environment on the behavior of an individual; they are presented as the social pressure perceived by an individual as a result of performing or not performing a particular behavior [5]. The pressure arises mainly when other persons important to him/her, like his/her family members and friends, think it is desirable or undesirable for him/her to perform a given behavior [6]. When a person perceives that people in his/her surroundings will support or affirm his/her behavior and he/she takes a positive attitude toward the behavior, he/she will have a very strong intention to perform that behavior.

\subsection{Control of perceived behavior}

The control of perceived behavior is an important variable in the theory of planned behavior. It is an individual's perception of the various obstacles he/she may encounter when performing a particular behavior. In other words, it is an individual's judgment of the level of difficulty when he/she performs a particular behavior according to his/her previous experience or expectations. When a person believes that he/she has relatively ample resources and opportunities (e.g. money, skills, help, etc.) and expects relatively little difficulties, the control of perceived behavior will be strong. To the contrary, if a person feels helpless in purchasing ethical apparel, his/her behavioral intention will be checked to a certain degree.

\section{Empirical study}

This article adopts the empirical analysis method. The empirical analysis consists mainly of the following steps: questionnaire design, testing, sampling and data collection, and data analysis.

The questionnaire for this study covers four aspects as follows:

(1) consumers' basic understanding of environmental issues and ethical apparel

We will try to understand consumers' understanding of environmental issues and ethical apparel by examining their knowledge of low carbon emission, environmental protection and ethical apparel and their recognition of ethical apparel.

(2) factors influencing consumers' ethical apparel purchasing behavior

We will examine the factors that influence consumers' ethical apparel purchasing behavior by looking at such elements as prices, colors and styles, fabric and workmanship, motivation for compliance, media and information.

(3) investigation of consumers' intention to purchase ethical apparel

We will study consumers' intention to purchase ethical apparel from such perspectives as prices, whether or not they will purchase ethical apparel in the future, and premium rate.

(4) personal information of survey respondents

Such information includes gender, age, occupation, employment, education, monthly income, and other basics. Respondents are required to answer every question and evaluate 
the degrees to which they agree with statements in the questionnaire. The questionnaire adopts a 7-point Likert scale, with 1 representing "completely disagree" and 7 "completely agree".

The sample survey was mainly conducted in Beijing. The sample was divided into two parts, namely the part for university students and the part for non-university students. The sampling was undertaken at the same time. A total of 260 questionnaires were distributed, with 245 retrieved. After a consistency check, 45 questionnaires were screened out. So there were a total of 200 effective questionnaires, with the recovery rate standing at $94.23 \%$ and the effective rate at $76.92 \%$.

\section{Descriptive statistical analyses}

We have made descriptive statistical analyses on the samples surveyed. The results of such analyses are shown in Table 1.

Table 1. Descriptions of the Samples Surveyed.

\begin{tabular}{|c|c|c|c|c|c|}
\hline Group varia & & Frequency & Percentage & $\begin{array}{l}\text { Effective } \\
\text { percentage }\end{array}$ & $\begin{array}{l}\text { Accumulatec } \\
\text { percentage }\end{array}$ \\
\hline Gender & $\begin{array}{l}\text { male } \\
\text { female }\end{array}$ & $\begin{array}{l}93 \\
107\end{array}$ & $\begin{array}{l}46.5 \\
53.5\end{array}$ & $\begin{array}{l}46.5 \\
53.5\end{array}$ & $\begin{array}{l}46.5 \\
100.0\end{array}$ \\
\hline $\begin{array}{l}\text { Monthly } \\
\text { income }\end{array}$ & $\begin{array}{l}\text { Less than } 1,000 \\
1,000-3,000 \\
3,000-5,000 \\
5,000-8,000 \\
8,000-10,000 \\
\text { More than } 10,000\end{array}$ & $\begin{array}{l}16 \\
41 \\
48 \\
33 \\
56 \\
6\end{array}$ & $\begin{array}{l}8 \\
20.5 \\
24.0 \\
16.5 \\
28.0 \\
3.0\end{array}$ & $\begin{array}{l}8 \\
20.5 \\
24.0 \\
16.5 \\
28.0 \\
3.0\end{array}$ & $\begin{array}{l}8 \\
28.5 \\
52.5 \\
69.0 \\
97.0 \\
100.0\end{array}$ \\
\hline \multirow{3}{*}{ Education } & $\begin{array}{l}\text { Secondary technical } \\
\text { schooling or below }\end{array}$ & 6 & 3.0 & 3.0 & 3.0 \\
\hline & $\begin{array}{l}\text { Junior college } \\
\text { Undergraduate }\end{array}$ & $\begin{array}{l}10 \\
147\end{array}$ & $\begin{array}{l}5.0 \\
73.5\end{array}$ & $\begin{array}{l}5.0 \\
73.5\end{array}$ & $\begin{array}{l}8.0 \\
81.5\end{array}$ \\
\hline & $\begin{array}{l}\text { Master's degree or } \\
\text { above }\end{array}$ & 37 & 18.5 & 18.5 & 100.0 \\
\hline Age & $\begin{array}{l}\text { Younger than } 20 \\
20-30 \\
30-40 \\
40-50 \\
\text { Older than } 50 \\
\end{array}$ & $\begin{array}{l}8 \\
89 \\
59 \\
30 \\
14 \\
\end{array}$ & $\begin{array}{l}4.0 \\
44.5 \\
29.5 \\
15.0 \\
7.0 \\
\end{array}$ & $\begin{array}{l}4.0 \\
44.5 \\
29.5 \\
15.0 \\
7.0 \\
\end{array}$ & $\begin{array}{l}4.0 \\
48.5 \\
78.0 \\
93.0 \\
100.0 \\
\end{array}$ \\
\hline \multirow{5}{*}{ Occupation } & $\begin{array}{l}\text { Government } \\
\text { employees } \\
\text { Company }\end{array}$ & 20 & 10.0 & 10.0 & 10.0 \\
\hline & $\begin{array}{l}\text { employees } \\
\text { Students }\end{array}$ & $\begin{array}{l}30 \\
100\end{array}$ & $\begin{array}{l}15.0 \\
50.0\end{array}$ & $\begin{array}{l}15.0 \\
50.0\end{array}$ & $\begin{array}{l}25.0 \\
75.0\end{array}$ \\
\hline & $\begin{array}{l}\text { Education, research } \\
\text { and medical } \\
\text { workers }\end{array}$ & 19 & 9.5 & 9.5 & 84.5 \\
\hline & $\begin{array}{l}\text { Self-employed } \\
\text { individuals }\end{array}$ & 24 & 12.0 & 12.0 & 96.5 \\
\hline & Others & 7 & 3.5 & 3.5 & 100.0 \\
\hline $\begin{array}{l}\text { Effective } \\
\text { sample size }\end{array}$ & 200 & & & & \\
\hline
\end{tabular}

This article uses SPSS19.0 to calculate the maximum value, minimum value, mean value and standard deviation of all variables observed. The results of calculation are shown in 
Tables 2 to 6 . The mean values of all observed variables for knowledge of apparel ethics are generally on the low side, with the minimum value at 2.58 (the second indicator), indicating that consumers know relatively little about ethical apparel. The mean values of all other variables are on the upper medium level. The standard deviations for all variables stand above 1 , indicating a relatively great difference in the choices of respondents in answering the survey questions.

Table 2. Descriptive Statistical Analyses on the Latent Variable "Product Attributes".

\begin{tabular}{|c|c|c|c|c|c|c|}
\hline & Observed variable & $\begin{array}{l}\text { Sample } \\
\text { size }\end{array}$ & $\begin{array}{l}\text { Minimum } \\
\text { value }\end{array}$ & $\begin{array}{l}\text { Maximu } \\
\text { m value }\end{array}$ & Mean value & $\begin{array}{l}\text { Stand } \\
\text { ard } \\
\text { deviat } \\
\text { ion }\end{array}$ \\
\hline \multirow{3}{*}{$\begin{array}{l}\text { Latent } \\
\text { variable }\end{array}$} & $\mathrm{A} 3.1$ & 200 & 1 & 6 & 4.89 & 0.955 \\
\hline & A 3.2 & 200 & 1 & 7 & 4.88 & 1.110 \\
\hline & A 3.3 & 200 & 1 & 7 & 4.96 & 0.926 \\
\hline $\begin{array}{l}\text { Effective } \\
\text { sample } \\
\text { size }\end{array}$ & & 200 & & & & \\
\hline
\end{tabular}

Table 3. Descriptive Statistical Analyses on the Latent Variable "Behavioral Attitude"

\begin{tabular}{|c|c|c|c|c|c|c|c|}
\hline $\begin{array}{l}\text { Latent } \\
\text { variable }\end{array}$ & $\begin{array}{l}\text { Latent sub- } \\
\text { variable }\end{array}$ & $\begin{array}{l}\text { Observe } \\
\mathrm{d} \\
\text { variable }\end{array}$ & $\begin{array}{l}\text { Sample } \\
\text { size }\end{array}$ & $\begin{array}{l}\text { Minimum } \\
\text { value }\end{array}$ & $\begin{array}{l}\text { Maximum } \\
\text { value }\end{array}$ & $\begin{array}{l}\text { Mean } \\
\text { value }\end{array}$ & $\begin{array}{l}\text { Stand } \\
\text { ard } \\
\text { deviat } \\
\text { ion } \\
\end{array}$ \\
\hline \multirow{10}{*}{$\begin{array}{l}\text { Behavior } \\
\text { al } \\
\text { attitude }\end{array}$} & \multirow{4}{*}{$\begin{array}{l}\text { Sense of } \\
\text { responsibil } \\
\text { ity for } \\
\text { environme } \\
\text { nt }\end{array}$} & A 1.1 & 200 & 2 & 7 & 4.35 & 1.132 \\
\hline & & A1.2 & 200 & 1 & 7 & 4.51 & 0.997 \\
\hline & & A1.3 & 200 & 1 & 7 & 4.56 & 0.975 \\
\hline & & A1.4 & 200 & 2 & 6 & 4.62 & 0.825 \\
\hline & \multirow{4}{*}{$\begin{array}{l}\text { Knowledg } \\
\text { e of } \\
\text { apparel } \\
\text { ethics }\end{array}$} & A2.1 & 200 & 2 & 6 & 3.01 & 1.132 \\
\hline & & $\mathrm{A} 2.2$ & 200 & 2 & 7 & 2.58 & 0.887 \\
\hline & & $\mathrm{A} 2.3$ & 200 & 1 & 6 & 3.50 & 1.032 \\
\hline & & A2.4 & 200 & 1 & 6 & 4.56 & 1.270 \\
\hline & \multirow{2}{*}{$\begin{array}{l}\text { Motivation } \\
\text { for } \\
\text { complianc } \\
\text { e }\end{array}$} & A5.1 & 200 & 1 & 7 & 4.69 & 1.028 \\
\hline & & A5.2 & 200 & 1 & 7 & 4.69 & 1.171 \\
\hline \multicolumn{3}{|c|}{ Effective sample size } & 200 & & & & \\
\hline
\end{tabular}

Table 4. Descriptive Statistical Analyses on the Latent Variable "Subjective Norms".

\begin{tabular}{|c|c|c|c|c|c|c|}
\hline $\begin{array}{l}\text { Latent } \\
\text { variable }\end{array}$ & $\begin{array}{l}\text { Observed } \\
\text { variable }\end{array}$ & Sample size & $\begin{array}{l}\text { Minimum } \\
\text { value }\end{array}$ & $\begin{array}{l}\text { Maximum } \\
\text { value }\end{array}$ & $\begin{array}{l}\text { Mea } \\
\mathrm{n} \\
\text { valu } \\
\mathrm{e}\end{array}$ & $\begin{array}{l}\text { Standard } \\
\text { deviation }\end{array}$ \\
\hline & A4.1 & 200 & 1 & 7 & 4.80 & 1.144 \\
\hline Subjectiv & A 4.2 & 200 & 2 & 6 & 4.46 & 0.955 \\
\hline e norms & A4.3 & 200 & 1 & 7 & 4.53 & 1.143 \\
\hline & A4.4 & 200 & 1 & 7 & 4.75 & 0.934 \\
\hline $\begin{array}{l}\text { Effective } \\
\text { sample } \\
\text { size }\end{array}$ & & 200 & & & & \\
\hline
\end{tabular}


Table 5. Descriptive Statistical Analyses on the Latent Variable "Control of Perceived Behavior".

\begin{tabular}{|c|c|c|c|c|c|c|}
\hline $\begin{array}{l}\text { Latent } \\
\text { variabl } \\
\mathrm{e}\end{array}$ & $\begin{array}{l}\text { Observe } \\
\mathrm{d} \\
\text { variable }\end{array}$ & Sample size & $\begin{array}{l}\text { Minimum } \\
\text { value }\end{array}$ & $\begin{array}{l}\text { Maximum } \\
\text { value }\end{array}$ & Mean value & $\begin{array}{l}\text { Standard } \\
\text { deviatio } \\
\mathrm{n}\end{array}$ \\
\hline Contro & A6.1 & 200 & 1 & 7 & 5.09 & 0.881 \\
\hline $\begin{array}{l}1 \text { of } \\
\text { percei }\end{array}$ & A6.2 & 200 & 1 & 7 & 5.06 & 0.897 \\
\hline $\begin{array}{l}\text { ved } \\
\text { behavi } \\
\text { or }\end{array}$ & A6.3 & 200 & 3 & 6 & 4.82 & 0.837 \\
\hline $\begin{array}{l}\text { Effecti } \\
\text { ve } \\
\text { sampl } \\
\text { e size }\end{array}$ & & 200 & & & & \\
\hline
\end{tabular}

Table 6. Descriptive Statistical Analyses on the Latent Variable "Behavioral Intention".

\begin{tabular}{lllllll}
\hline $\begin{array}{l}\text { Latent } \\
\text { variable }\end{array}$ & $\begin{array}{l}\text { Observed } \\
\text { variable }\end{array}$ & $\begin{array}{l}\text { Sample } \\
\text { size }\end{array}$ & $\begin{array}{l}\text { Minimum } \\
\text { value }\end{array}$ & $\begin{array}{l}\text { Maximum } \\
\text { value }\end{array}$ & $\begin{array}{l}\text { Mean } \\
\text { value }\end{array}$ & $\begin{array}{l}\text { Standard } \\
\text { deviation }\end{array}$ \\
\hline Behavioral & A7.1 & 200 & 3 & 7 & 5.31 & 0.741 \\
intention & A7.2 & 200 & 2 & 6 & 4.88 & 0.940 \\
Effective & A7.3 & 200 & 2 & 7 & 4.87 & 0.791 \\
sample size & & 200 & & & & \\
\hline
\end{tabular}

The premium of a product can be seen as the difference between the price of the product and the average price of similar products. If the price of ethical apparel is set too high, consumers may not be willing to purchase ethical apparel at the cost of part of their personal interest. Therefore, the premium rate of ethical apparel must be controlled within a reasonable range to make it more easily accepted by consumers. The premium rates acceptable to consumers as shown by studies in this article are presented in Table 7. It can be seen that $89.5 \%$ of the respondents accept a premium rate of lower than $15 \%$ for ethical apparel.

Table 7. Premium Rates Acceptable to Consumers.

\begin{tabular}{lllll}
\hline $\begin{array}{l}\text { Group } \\
\text { variable }\end{array}$ & Frequency & $\begin{array}{l}\text { Proportion of consumers } \\
\text { who accept }\end{array}$ & $\begin{array}{l}\text { Effective } \\
\text { percentage }\end{array}$ & $\begin{array}{l}\text { Accumulated } \\
\text { percentage }\end{array}$ \\
\hline Lower than & 25 & 12.5 & 12.5 & 12.5 \\
$5 \%$ & 36 & 18.0 & 18.0 & 30.5 \\
$5-10 \%$ & 118 & 59.0 & 59.0 & 89.5 \\
$10-15 \%$ & 7 & 3.5 & 3.5 & 93.0 \\
$15-20 \%$ & 4.0 & 4.0 & 97.0 \\
$20-25 \%$ & 8 & 3.0 & 3.0 & 100.0 \\
Higher than & 6 & 100.0 & 100.0 & \\
$25 \%$ & 200 & & \\
Total & & &
\end{tabular}

The times of ethical apparel purchasing done by consumers in the past are shown in Table 8. $24.0 \%$ of the consumers surveyed had never purchased ethical apparel. Even if they had done so, the frequency was extremely low. 
Table 8. Ethical Apparel Purchasing History.

\begin{tabular}{lllll}
\hline Group variable & Frequency & Percentage & $\begin{array}{l}\text { Effective } \\
\text { percentage }\end{array}$ & $\begin{array}{l}\text { Accumulated } \\
\text { percentage }\end{array}$ \\
\hline $\begin{array}{l}\text { Never } \\
\begin{array}{l}\text { Once every 10 instances of } \\
\text { apparel purchasing }\end{array}\end{array}$ & 48 & 24.0 & 24.0 & 24.0 \\
$\begin{array}{l}\text { 2 to 3 times every 10 instances } \\
\text { of apparel purchasing }\end{array}$ & 51 & 39.0 & 39.0 & 63.0 \\
$\begin{array}{l}4 \text { to 5 times every 10 instances } \\
\text { of apparel purchasing }\end{array}$ & 15 & 25.5 & 25.5 & 88.5 \\
$\begin{array}{l}\quad \text { to 7 times every 10 instances } \\
\text { of apparel purchasing }\end{array}$ & 4 & 7.5 & 7.5 & 96.0 \\
8 to 9 times every 10 instances & 1 & 2.0 & 2.0 & 98.0 \\
$\begin{array}{l}\text { of apparel purchasing } \\
\text { Always }\end{array}$ & 3 & 0.5 & 0.5 & 98.5 \\
Total & 200 & 1.5 & 1.5 & 100.0 \\
\hline
\end{tabular}

\section{Reliability analyses}

This article uses Cronbach's $\alpha$ as the standard to check the reliability of the questionnaire. The CITC must not be lower than 0.5; otherwise, the tested item concerned will be removed. This article conducts reliability analyses with respect to product attributes, behavioral attitude, subjective norms, control of perceived behavior, and behavioral intention in the original scale, with the results of analyses shown in Table 9. As shown in the table, the CITC value of A2.4 and A4.1 is 0.201 and 0.175 respectively, so the two items are deleted. The results also indicate that the Cronbach's $\alpha$ of various items is higher than the critical value of 0.6 , fully indicating the relatively high reliability of the data for the variables studied. Moreover, the CITC values of all variables are greater than 0.4 , indicating that all items are within the meaning of the variables and can truly describe the meaning of variables. Furthermore, deleting any item will not significantly raise the value of Cronbach's $\alpha$, indicating that the scale adopted in this article has a relatively high level of internal consistency.

Table 9. Results of Scale Reliability Analyses.

\begin{tabular}{|c|c|c|c|c|c|}
\hline $\begin{array}{l}\text { Latent } \\
\text { variable }\end{array}$ & Identifier variable & CITC (CITC) & $\begin{array}{l}\text { Deleted } \alpha \\
\text { value } \\
\text { under item }\end{array}$ & $\begin{array}{l}\alpha \\
\text { value }\end{array}$ & $\begin{array}{l}\alpha \\
\text { value }\end{array}$ \\
\hline \multirow{3}{*}{$\begin{array}{l}\text { Product } \\
\text { attributes ( } 3 \\
\text { questions) }\end{array}$} & $\begin{array}{l}\text { A3.1 (the degree to which prices } \\
\text { sway my ethical apparel } \\
\text { purchasing behavior) }\end{array}$ & 0.730 & 0.841 & \multirow{3}{*}{0.83} & \multirow{3}{*}{0.81} \\
\hline & $\begin{array}{l}\text { A3.2 (the degree to which colors } \\
\text { sway my ethical apparel } \\
\text { purchasing behavior) }\end{array}$ & 0.651 & 0.739 & & \\
\hline & $\begin{array}{l}\text { A3.3 (the degree to which fabric } \\
\text { and workmanship sway my } \\
\text { ethical apparel purchasing } \\
\text { behavior) }\end{array}$ & 0.654 & 0.732 & & \\
\hline \multirow{2}{*}{$\begin{array}{l}\text { Behavioral } \\
\text { attitude ( } 10 \\
\text { questions) }\end{array}$} & $\begin{array}{l}\text { A1.1 (I am willing to sacrifice } \\
\text { my personal interest for }\end{array}$ & 0.753 & 0.753 & \multirow{2}{*}{0.78} & \multirow{2}{*}{0.76} \\
\hline & $\begin{array}{l}\text { A1.2 (I will take the initiative to } \\
\text { communicate environmental } \\
\text { protection knowledge) }\end{array}$ & 0.644 & 0.644 & & \\
\hline
\end{tabular}




\begin{tabular}{|c|c|c|c|c|c|}
\hline & $\begin{array}{l}\text { A1.3 (I will use degradable } \\
\text { shopping bags when shopping) }\end{array}$ & 0.520 & 0.520 & & \\
\hline & $\begin{array}{l}\text { A1.4 (I will consider whether the } \\
\text { enterprise concerned has the } \\
\text { sense of social responsibility } \\
\text { when purchasing) }\end{array}$ & 0.523 & 0.523 & & \\
\hline & $\begin{array}{l}\text { A2.1 (I know ethical apparel } \\
\text { quite well) }\end{array}$ & 0.705 & 0.705 & & \\
\hline & $\begin{array}{l}\text { A2.2 (I will check whether the } \\
\text { product has environmental } \\
\text { protection logos when } \\
\text { purchasing) }\end{array}$ & 0.562 & 0.562 & & \\
\hline & $\begin{array}{l}\text { A2.3 (I can correctly identify } \\
\text { ethical apparel) }\end{array}$ & 0.552 & 0.552 & & \\
\hline & $\begin{array}{l}\text { A2.4 (There are many ethical } \\
\text { apparel options on the current } \\
\text { market) }\end{array}$ & 0.201 & 0.201 & & \\
\hline & $\begin{array}{l}\text { A5.1 (If people around me often } \\
\text { buy ethical apparel, I will buy it, } \\
\text { too) }\end{array}$ & 0.533 & 0.533 & & \\
\hline & $\begin{array}{l}\text { A5.2(If government or media call } \\
\text { on me to buy ethical apparel, I } \\
\text { will) }\end{array}$ & 0.591 & 0.591 & & \\
\hline \multirow{4}{*}{$\begin{array}{l}\text { Subjective } \\
\text { norms }(4 \\
\text { questions) }\end{array}$} & $\begin{array}{l}\text { A4.1 (Choosing non-ethical } \\
\text { apparel will make me feel guilty) }\end{array}$ & 0.175 & 0.175 & \multirow{4}{*}{0.79} & \multirow{4}{*}{0.73} \\
\hline & $\begin{array}{l}\text { A4.2 (Purchasing ethical apparel } \\
\text { gives me a sense of pride) }\end{array}$ & 0.583 & 0.583 & & \\
\hline & $\begin{array}{l}\text { A4.3 (Purchasing ethical apparel } \\
\text { can win respect from others) }\end{array}$ & 0.726 & 0.726 & & \\
\hline & $\begin{array}{l}\text { A } 4.4 \text { (I may choose to buy } \\
\text { ethical products if I am willing } \\
\text { to) }\end{array}$ & 0.587 & 0.587 & & \\
\hline \multirow{3}{*}{$\begin{array}{l}\text { Control of } \\
\text { perceived } \\
\text { behavior ( } 3 \\
\text { questions) }\end{array}$} & $\begin{array}{l}\text { A6.1 (I will buy it often if I have } \\
\text { sufficient money, time or } \\
\text { opportunity) }\end{array}$ & 0.633 & 0.633 & \multirow{3}{*}{0.77} & \multirow{3}{*}{0.72} \\
\hline & $\begin{array}{l}\text { A6.2 (I will buy ethical products } \\
\text { if there are sufficient referential } \\
\text { information) }\end{array}$ & 0.621 & 0.621 & & \\
\hline & $\begin{array}{l}\text { A6.3 (I will buy ethical products } \\
\text { if there are sufficient options of } \\
\text { such products) }\end{array}$ & 0.534 & 0.534 & & \\
\hline \multirow{3}{*}{$\begin{array}{l}\text { Behavioral } \\
\text { intention ( } 3 \\
\text { questions) }\end{array}$} & $\begin{array}{l}\text { A7.1 (I will buy ethical products } \\
\text { first under the same prices) }\end{array}$ & 0.665 & 0.665 & \multirow{3}{*}{0.81} & \multirow{3}{*}{0.80} \\
\hline & $\begin{array}{l}\text { A7.2 (I will buy ethical products } \\
\text { even if they are more expensive) }\end{array}$ & 0.559 & 0.559 & & \\
\hline & $\begin{array}{l}\text { A7.3 (I will try buying ethical } \\
\text { apparel after this survey) }\end{array}$ & 0.647 & 0.647 & & \\
\hline
\end{tabular}

Note: As the CITC value for A2.4 (There are many ethical apparel options on the current market) and A4.1 (Choosing non-ethical apparel will make me feel guilty) stands at 0.201 and 0.175 respectively, the two items are therefore deleted. 


\section{Confirmatory factor analyses}

Validity is the ability of a scale to measure the thing it is designed to measure [7]. This article chooses confirmatory factor analyses to test the validity of the model adopted in this article. Factor analyses are methods that explore whether there are potential factors that cannot be directly observed but may play a dominant role with regard to changes in the observable correlated variables. They are methods to look for potential factors that play dominant roles. Confirmatory factor analyses are mainly used to check the accuracy of testing models and whether the observed variables can fully represent latent variables, as well as the overall reliability and validity of the questionnaire.

We use statistical software to conduct factor analyses on the data collected. After strictly screening and checking the observed variables, we find that the extracted value of A5.2 stands at 0.5 , which is relatively low and therefore cannot represent the data well. Moreover, the extracted value of items A3.3, A1.3 and A6.2 stands at $0.525,0.525$ and 0.512 respectively. They are all on the low side and therefore relatively poorly representative of the data concerned, so they are all deleted. Tables 10 to 13 present the results of post-deletion analyses. Generally speaking, when KMO is higher than 0.7 , the data concerned are basically suitable for factor analyses. Table 10 presents the results of KMO and Bartlett's tests after data screening. It is clear that the result of the KMO test is 0.804 , higher than the required 0.7 , indicating that the data are highly suitable for factor analyses. The significance level for the Bartlett's test is 0.000 , far lower than 0.05 , also indicating the suitability of the data for factor analyses.

Table 10. KMO and Bartlett's Tests.

\begin{tabular}{ll}
\hline $\begin{array}{l}\text { Kaiser-Meyer-Olkin measure of sampling } \\
\text { adequacy }\end{array}$ & 0.804 \\
\hline Chi-squared approximation for Bartlett's test & 350.904 \\
df & 136 \\
Sig. & 0.000 \\
\hline
\end{tabular}

Table 11. Common Factor Variance (Second Time).

\begin{tabular}{lll}
\hline Items & Initial & Extracted \\
\hline A3.1 & 1.000 & 0.679 \\
A3.2 & 1.000 & 0.682 \\
A1.1 & 1.000 & 0.669 \\
A1.2 & 1.000 & 0.689 \\
A1.4 & 1.000 & 0.574 \\
A2.1 & 1.000 & 0.720 \\
A2.2 & 1.000 & 0.775 \\
A2.3 & 1.000 & 0.659 \\
A5.1 & 1.000 & 0.683 \\
A4.2 & 1.000 & 0.533 \\
A4.3 & 1.000 & 0.599 \\
A4.4 & 1.000 & 0.634 \\
A6.1 & 1.000 & 0.707 \\
A6.3 & 1.000 & 0.698 \\
A7.1 & 1.000 & 0.589 \\
A7.2 & 1.000 & 0.660 \\
& & 0.706 \\
A7.3 & 1.000 & \\
& & \\
\hline
\end{tabular}


Table 12. Total Variance Explained.

\begin{tabular}{|c|c|c|c|c|c|c|c|c|c|}
\hline \multirow[t]{2}{*}{$\begin{array}{l}\text { Com } \\
\text { pone } \\
\text { nt }\end{array}$} & \multicolumn{3}{|c|}{ Initial eigenvalue } & \multicolumn{3}{|c|}{$\begin{array}{l}\text { Extraction sums of squared } \\
\text { loadings }\end{array}$} & \multicolumn{3}{|c|}{$\begin{array}{l}\text { Rotation sums of squared } \\
\text { loadings }\end{array}$} \\
\hline & Total & $\begin{array}{l}\% \text { of } \\
\text { varian } \\
\text { ce }\end{array}$ & $\begin{array}{l}\text { Accumulate } \\
\text { d \% }\end{array}$ & $\begin{array}{l}\text { Tot } \\
\text { al }\end{array}$ & $\begin{array}{l}\% \text { of } \\
\text { varian } \\
\text { ce }\end{array}$ & $\begin{array}{l}\text { Accumulate } \\
\mathrm{d} \%\end{array}$ & $\begin{array}{l}\text { Tot- } \\
\text { al }\end{array}$ & $\begin{array}{l}\% \text { of } \\
\text { varian } \\
\text { ce }\end{array}$ & $\begin{array}{l}\text { Accumulate } \\
\mathrm{d} \%\end{array}$ \\
\hline 1 & 3.425 & $\begin{array}{l}25.29 \\
9\end{array}$ & 25.299 & $\begin{array}{l}3.42 \\
5\end{array}$ & $\begin{array}{l}25.29 \\
9\end{array}$ & 25.299 & $\begin{array}{l}4.02 \\
1\end{array}$ & $\begin{array}{l}32.78 \\
6\end{array}$ & 32.786 \\
\hline 2 & 3.211 & $\begin{array}{l}23.71 \\
0\end{array}$ & 49.009 & $\begin{array}{l}3.21 \\
1\end{array}$ & $\begin{array}{l}23.71 \\
0\end{array}$ & 49.009 & $\begin{array}{l}2.98 \\
0\end{array}$ & $\begin{array}{l}24.30 \\
4\end{array}$ & 57.090 \\
\hline 3 & 1.706 & $\begin{array}{l}12.60 \\
0\end{array}$ & 61.609 & $\begin{array}{l}1.70 \\
6\end{array}$ & $\begin{array}{l}12.60 \\
0\end{array}$ & 61.609 & $\begin{array}{l}1.23 \\
1\end{array}$ & $\begin{array}{l}10.03 \\
9\end{array}$ & 67.129 \\
\hline 4 & 1.125 & 8.311 & 69.920 & $\begin{array}{l}1.12 \\
5\end{array}$ & 8.311 & 69.920 & $\begin{array}{l}0.34 \\
2\end{array}$ & 2.791 & 69.920 \\
\hline 5 & 0.654 & 4.831 & 74.751 & & & & & & \\
\hline 6 & 0.531 & 3.922 & 78.673 & & & & & & \\
\hline 7 & 0.476 & 3.516 & 82.189 & & & & & & \\
\hline 8 & 0.476 & 3.516 & 85.705 & & & & & & \\
\hline 9 & 0.312 & 2.305 & 88.010 & & & & & & \\
\hline 10 & 0.260 & 1.921 & 89.931 & & & & & & \\
\hline 11 & 0.232 & 1.714 & 91.645 & & & & & & \\
\hline 12 & 0.216 & 1.595 & 93.240 & & & & & & \\
\hline 13 & 0.202 & 1.492 & 94.732 & & & & & & \\
\hline 14 & 0.202 & 1.492 & 96.224 & & & & & & \\
\hline 15 & 0.200 & 1.477 & 97.701 & & & & & & \\
\hline 16 & 0.200 & 1.477 & 99.178 & & & & & & \\
\hline 17 & 0.081 & 0.822 & 100.000 & & & & & & \\
\hline
\end{tabular}

Table 13. Rotated Component Matrix.

\begin{tabular}{lllll}
\hline Item & Component 1 & Component 2 & Component 3 & Component 4 \\
\hline A3.1 & 0.825 & 0.125 & 0.342 & 0.290 \\
A3.2 & 0.067 & 0.234 & 0.378 & 0.694 \\
A1.1 & 0.321 & 0.098 & 0.521 & 0.225 \\
A1.2 & 0.635 & 0.257 & 0.136 & 0.289 \\
A1.4 & 0.901 & 0.237 & 0.102 & 0.106 \\
A2.1 & 0.034 & 0.432 & 0.531 & 0.369 \\
A2.2 & 0.261 & 0.394 & 0.724 & 0.105 \\
A2.3 & 0.098 & 0.278 & 0.038 & 0.844 \\
A5.1 & 0.385 & 0.274 & 0.641 & 0.056 \\
A4.2 & 0.202 & 0.156 & 0.373 & 0.742 \\
A4.3 & 0.407 & 0.162 & 0.236 & 0.178 \\
A4.4 & 0.359 & 0.270 & 0.503 & 0.314 \\
A6.1 & 0.632 & 0.269 & 0.162 & 0.342 \\
A6.3 & 0.544 & 0.170 & 0.210 & 0.219 \\
A7.1 & 0.179 & 0.538 & 0.366 & 0.272 \\
A7.2 & 0.369 & 0.491 & 0.274 & 0.215 \\
A7.3 & 0.359 & 0.274 & 0.721 & 0.134 \\
\hline
\end{tabular}

Table 12 lists the total variance contribution ratio for the factor analyses. It shows that four factors are extracted in the end and their variance contribution ratio to the entire variables stands at $25.299 \%, 23.710 \%, 12.600 \%$ and $8.311 \%$ respectively. The factors correspond to latent variables: behavioral attitude, subjective norms, product attributes, and control of perceived behavior respectively, with their total contribution ratio reaching $69.920 \%$. 
From the results of the foregoing confirmatory factor analyses, we arrive at the conclusion that the four hypotheses made by this study all hold water. Nevertheless, behavioral attitude, product attributes, subjective norms and control of perceived behavior affect the intention to purchase ethical apparel to varying degrees. Behavioral attitude has the most significant impact on the purchasing intention, followed by subjective norms, product attributes and control of perceived behavior in decreasing order of the significance level of their impact.

\section{Conclusions and recommendations}

All the hypotheses made for the theoretical model of this study, namely, H1, H2, H3 and H4, all hold water. That's to say, the four latent variables, i.e. behavioral attitude, subjective norms, product attributes and control of perceived behavior, all have significant positive impact on the intention to purchase ethical apparel. Specifically, behavioral attitude has the greatest impact on ethical apparel consumption behavior, followed by subjective norms, product attributes and control of perceived behavior in decreasing order of the significance level of their impact.

From the finding of this study, we can see that the behavioral attitude of consumers has the greatest impact on behavioral intention. Therefore, we must deepen consumers' knowledge and understanding of ethical apparel and communicate and popularize ethical apparel-related knowledge to foster positive behavioral attitude on the part of consumers. In doing so, we must take the feelings of consumers into consideration, so that consumers can obtain more information about ethical apparel and gain deeper understanding of ethical apparel by osmosis. From the study finding, we can also see that product attributes also play a significant role in influencing behavioral intention. Therefore, the foregoing actions can serve to disseminate environmental protection concepts to consumers, too, thus enhancing their awareness of environmental protection, creating an atmosphere in favor of environmental protection in society, and establishing influential reference groups that play exemplary roles. They enhance consumers' behavioral intention by strengthening their behavioral attitude and subjective norms.

In our study, consumers express their willingness to support fashion-related ethical business yet their shortage of related knowledge. Therefore, they could not accurately identify ethical fashion products in shopping. Moreover, consumers who had actually experienced ethical consumption were quite few. Therefore, providing consumers with relevant guidance and education is especially important for improving their awareness of fashion ethics. For this reason, apparel enterprises must make full use of various media to conduct more effective communication with consumers and make correct releases and disclosures of information on social responsibility to targeted consumer groups through certain channels on a regular basis. This will significantly lower the information identification cost on the part of consumers and in turn promote actual ethical purchasing.

In addition, this study finds that consumers are willing to pay premium prices for ethical fashion products and the premium rate acceptable to them ranges from $11 \%$ to $15 \%$. Therefore, retailers must ensure that their ethical fashion products are not priced at a level $15 \%$ higher than that of similar products. This finding can provide ethical fashion retailers with relatively good guidance in pricing their products.

Finally, this study finds that consumers pay special attention to the impact dealt by textile and apparel enterprises on environment and that the environmental protection awareness of the general public has significantly heightened. People have realized that they must take the path of sustainable development featuring the harmony between human and nature. It can be said that Chinese consumers tend to attach greater importance to the positive role of ethical fashion products in relation to environmental protection. This points out the right direction for retailers in doing ethical marketing: their product release events and advertisement must 
highlight the effect of environmental protection wherever possible, so as to strike a chord with their consumers.

\section{Acknowledgements}

This paper is funded by the project: General Project of Social Science Program of Beijing Municipal Education Commission (No.: SM202010012001, Name: New Retail Driven Clothing Enterprise Business Model Innovation Research).

\section{References}

1. X M Deng, Study on Ethical Purchasing Intention of Consumers under Chinese Scenarios-Based upon TPB Perspective, in Nankai Business Review,15(3),22-32 (2012)

2. T H Stone, I.M. Jawahar, J.L. Kisamore, Using the Theory of Planned Behavior and Cheating Justifications to Predict Academic Misconduct, in Career Development International, 14(3),221-241 (2009)

3. M A Elliott, C J Armitage, C J Baughan, Using the Theory of Planned Behavior to Predict Observed Driving Behavior, in British Journal of Social Psychology, 46(1),6990 (2007)

4. H M Kang, D R Fortin, Y J Hyun, Y Eom, Effects of Perceived Behavioral Control on the Consumer Usage Intention of E-coupons, in Psychology \& Marketing, 23(10),841864 (2006)

5. C Joergens, Ethical fashion: myth or future trend in Journal of Fashion Marketing and Management, 10(3),360-371 (2006)

6. W D Lu, SPSS Statistical Analysis (Publishing House of Electronics Industry, Beijing, 2003)

7. C.Armitage, M.Conner. Efficacy of The Theory of Planned Behavior: A Meta-analytic Review, in British Journal of Social Psychology, 40(4),471-499 (2001) 